\title{
PENERAPAN MODEL PEMBELAJARAN TIPE STAD (STUDEN TEAM ACHIEVEMENT DIVISION) DALAM MENINGKATKAN MINAT BELAJAR SISWA PADA MATA PELAJARAN PKn DI SMP NEGERI 4 BEO DI LOBBO
}

\author{
Oleh: \\ Leidi Tandea, Sjamsi Pasandaran, Theodorus Pangalila \\ Jurusan PPKn FIS Unima \\ Email: spasandaran@unima.ac.id
}

\begin{abstract}
ABSTRAK
Dalam penelitian ini ditemukan berbagai permasalahan seputar minat belajar siswa antara lain: tidak memiliki minat belajar dalam pelajaran PKn, kurangnya perhatian siswa dalam proses belajar mengajar, siswa pasif dan hanya guru yang aktif, tidak memiliki semangat untuk belajar pelajaran PKn, dan tidak membuat tugas yang diberikan oleh guru. Adapun yang menjadi tujuan dari penelitian ini adalah untuk memperoleh informasi tentang penerapan model pembelajaran Kooperatif tipe STAD (Student Team Achievement Division) untuk meningkatkan minat belajar siswa pada mata pelajaran PKn di SMP Negeri 4 Beo di Lobbo. Metode penelitian yang digunakan dalam karya ilmiah ini adalah metode penelitian deskriptif naratif dengan pendekatan kualitatif, dimana peneliti ingin menggambarkan suatu fakta yang ada disekolah. Tujuan dari penelitian ini yaitu untuk mengetahui bagaimana penerapan model pembelajaran kooperatif tipe STAD dalam meningkatkan minat belajar siswa pada mata pelajaran PKn di SMP negeri 4 Beo di Lobbo. Hasil penelitian menunjukkan bahwa model pembelajaran tipe STAD yang sudah diterapkan dapat meningkatkan minat belajar siswa dan dapat menciptakan pembelajaran yang menarik sehingga siswa tertarik untuk belajar dan ikut berpartisipasi dalam proses belajar. Dan pada model pembelajaran kooperatif tipe STAD ini diskusi dan kerja kelompok memberikan kesempatan kepada siswa untuk dapat berpikir, berdiskusi bersama teman-teman sekelompoknya dan membuat kuis yang membuat siswa tertarik untuk belajar. Oleh karena itu, penulis merekomendasikan untuk penelitian selanjutnya agar dalam meningkatkan minat belajar siswa maka guru dapat menggunakan model pembelajaran kooperatif tipe STAD (Student Team Achievement Division).
\end{abstract}

Kata Kunci : Kooperatif Tipe STAD, Minat Belajar, PKn 


\section{PENDAHULUAN}

Pendidikan Kewarganegaraan (PKn) merupakan salah satu mata pelajaran yang mencakup ilmu politik, ilmu hukum, moral, sosial, administrasi negara dan memiliki peranan penting dalam meningkatkan kualitas manusia Indonesia. Oleh karena itu pendidikan kewarganegaraan perlu diajarkan kepada para peserta didik sebagai generasi penerus bangsa. Numan Sumantri, (2001:166) mengartikan Pendidikan Kewarganegaraan sebagai usaha sadar yang dilakukan secara ilmiah dan psikologis untuk memberikan kemudahan belajar kepada peserta didik agar terjadi internalisasi moral pancasila dan pengetahuan kewarganegaraan untuk melandasi tujuan pendidikan nasional yang diwujudkan dalam integritas pribadi dan perilaku sehari-hari. Menurut Winataputra dan Budimansyah, (2007:i) dalam Pangalila (2017) Pendidikan Kewarganegaraan (Civic Education) merupakan subjek pembelajaran yang mengemban misi untuk membentuk kepribadian bangsa, yakni sebagai upaya sadar dalam "nation and character building."

Salah satu perwujudan integritas pribadi bagi peserta didik adalah dengan melakukan pembelajaran di kelas. Maksudnya pembelajaran PKn yang diajarkan oleh guru di sekolah harus dapat melandasi tujuan nasional yang dimaksudkan di atas. Namun demikian secara umum proses pembelajaran PKn yang dilakukan oleh guru di sekolah hanya menggunakan metode ceramah dalam menyampaikan materi pelajaran. Sehingga menimbulkan kebosanan atau kejenuhan yang dapat mempengaruhi aktivitas belajar siswa dan akibatnya perhatian siswa terhadap pembelajaran menjadi berkurang. Selain itu interaksi belajar mengajar yang dilakukan oleh siswa sebagai pembelajar dan guru sebagai pengajar dapat menimbulkan masalah-masalah belajar seperti Dimyati dan Mudjiono, (2002:261) berpendapat bahwa faktor intern yang dialami dan dihayati oleh siswa meliputi hal-hal seperti berikut: a) Sikap terhadap belajar; b) Motivasi belajar; c) Konsentrasi belajar; d) Kemampuan mengolah bahan ajar; e) Kemampuan menyimpan perolehan hasil belajar; f) Kemampuan menggali hasil belajar yang tersimpan; g) Kemampuan berprestasi atau unjuk hasil belajar; h) Rasa percaya diri siswa; i) Intelegensi dan keberhasilan belajar; j) Kebiasaan belajar, dan; k) Cita-cita siswa.

Berkenaan dengan itu, maka guru sebagai pengajar memiliki kewajiban mencari, menemukan, dan diharapkan mampu memecahkan masalah-masalah dalam kegiatan belajar siswa. Sebagai guru profesional, diharapkan guru memiliki kemampuan dalam menerapkan keterampilan mengajar agar dapat menciptakan suasana belajar yang kondusif dan menyenangkan para peserta didik dalam mengikuti kegiatan pembelajaran. Sebab dalam kapasitas seperti itu, mereka dituntut menjadi tenaga profesional. Kedudukan guru sebagai tenaga profesional yang berfungsi meningkatkan martabat dan peran guru sebagai agen pembelajaran dilaksanakan berdasarkan prinsip sebagaimana yang dtetapkan dalam UndangUndang Guru dan Dosen Nomor 14 Tahun 2005 diantaranya dikatakan bahwa guru harus memiliki kompetensi yang diperlukan sesuai dengan bidang tugas, memiliki tanggung jawab atas pelaksanaan tugas keprofesionalan. Dalam menjalankan tugas keprofesionalan, guru wajib merencanakan pembelajaran, melaksanakan proses pembelajaran yang bermutu dengan mengimplementasikan variasi-variasi mengajar yang inovatif agar tercipta suasana pembelajaran yang aktif, inovatif, kreatif, efektif dan menyenangkan supaya tercipta suasana belajar yang menunjang keberhasilan belajar.

Seringkali banyak hal yang menyebabkan proses pembelajaran pada mata pelajaran PKn menjadi sulit dan tidak menyenangkan untuk dipelajari. Baik itu faktor dari guru maupun faktor dari peserta didik. Salah satu penyebabnya adalah cara 
guru mengajar yang monoton sehingga menyebabkan peserta didik merasa bosan yang mengakibatkan peserta didik tidak termotivasi untuk belajar. Sehingga diharapkan dalam pelaksanaan proses pembelajaran guru hendaknya memilih menggunakan strategi yang melibatkan peserta didik aktif belajar, baik secara mental, intelektual, fisik maupun sosial. Faktor dari peserta didik adalah sebagian besar peserta didik beranggapan bahwa kehadiran mereka disekolah hanyalah sebagai rutinitas yang mereka lakukan setiap hari untuk mengisi absen di kelas. Sehingga dalam proses belajar mengajar peserta didik hanya duduk, mendengarkan penjelasan guru dan mencatat (Dimyati, 2002:46).

Untuk itu di dalam proses belajar mengajar guru harus memiliki strategi atau mampu menggunakan model-model pembelajaran yang disesuaikan dengan kondisi kelas saat itu agar siswa bisa belajar secara efektif dan efisien. Untuk mencapai pengajaran yang baik dan dapat membangkitkan semangat belajar siswa maka diperlukan model pembelajaran yang dapat meningkatkan kreatifitas dan keaktifan siswa dalam proses pembelajaran yang ditandai dengan aktivitas siswa yang meningkat sehingga ketuntasan belajar siswa dapat tercapai.

Berdasarkan observasi awal penelitian di SMP Negeri 4 Beo di Lobbo dimana peneliti menemukan bahwa banyak siswa yang kurang tertarik untuk belajar, banyak yang hanya bermain ketika guru sedang menjelaskan, guru kurang kreatif dalam menerapkan model pembelajaran sehingga membuat siswa bosan dan tidak tertarik dengan mata pelajaran PKn, selain itu saat proses pembelajaran yang berperan aktif adalah Guru dan siswa hanya pasif tidak mampu berpartisipasi aktif. Hal ini terlihat dari suasana kelas dimana guru menerangkan terus sedangkan siswa hanya mendengar penjelasan yang disampaikan guru.

Mencermati hal tersebut di atas, maka perlu perbaikan yang dapat mengoptimalkan proses pembelajaran dan meningkatkan minat belajar peserta didik. Salah satu pendekatan yang dianjurkan dalam Kurikulum Tingkat Satuan Pendidikan (KTSP) adalah pendekatan pengajaran dan penerapan Pembelajaran Kooperatif Tipe STAD (Student Team Achievement Division). Dengan menggunakan model pembelajaran Kooperatif tipe STAD ini, peserta didik bisa mengemukakan gagasangagasan terhadap pemecahan masalah dalam kelompoknya, selain itu juga dalam model pembelajaran Kooperatif tipe STAD ini, peserta didik dilatih untuk bekerja sama, bertanggung jawab dan menumbuhkan rasa saling ketergantungan antara satu dengan yang lainnya (Suprijono, 2009:32).

Berdasarkan masalah yang dikemukakan di atas, peneliti hanya membatasi pada masalah Penerapan Model Pembelajaran Kooperatif Tipe STAD (Student Team Achievement Division) Dalam Meningkatkan Minat Belajar Siswa Pada Mata Pelajaran PKn Di SMP Negeri 4 Beo di Lobbo.

\section{METODOLOGI PENELITIAN}

Menurut Sugiyono, (2010:2) metode penelitian pada dasarnya merupakan cara ilmiah untuk mendapatkan data dengan tujuan dan kegunaan tertentu.

Sehubungan dengan itu, maka metode yang digunakan dalam penelitian ini adalah metode penelitian deskriptif naratif dengan pendekatan kualitatif. Menurut Arikunto, (2002:3) penelitian deskriptif adalah penelitian yang mempunyai tujuan untuk menggambarkan keadaan suatu atau status fenomena, dalam hal ini peneliti hanya ingin mengetahui hal-hal yang berhubungan dengan keadaan sesuatu.

Tempat pelaksanaan penelitian ini dilakukan di SMP Negeri 4 Beo di Lobbo. Waktu penelitian dilakukan selama 1 bulan. Adapun subjek penelitian ini ialah siswa kelas VIIIA di SMP Negeri 4 Beo di Lobbo yang berjumlah 58 siswa, yang terdiri dari 32 laki-laki dan 26 perempuan. Dan 1 orang Guru Mata Pelajaran PKn. 
Dalam penelitian, teknik pengumpulan data merupakan faktor penting demi keberhasilan penelitian. Hal ini berkaitan dengan bagaimana cara mengumpulkan data, siapa sumbernya, dan apa alat yang digunakan. Metode pengumpulan data ialah teknik atau caracara yang digunakan oleh peneliti untuk mengumpulkan data, (Ridwan, 2010:69). Adapun teknik data yang digunakan dalam pengumpulan data adalah sebagai berikut: Observasi, Dokumentasi

Rumusan yang digunakan dalam analisis data ini adalah dengan teknik analisis deskriptif kualitatif. Dalam penelitian ini, teknik analisis data lebih banyak dilakukan bersamaan dengan pengumpulan data yang tahapannya mengikuti analisis data kualitatif menurut Miles dan Huberman (sugiyono, 2010:294), yaitu dilakukan secara interaktif melalui proses pemilihan data, penyusunan data, serta melakukan interpretasi makna.

\section{PEMBAHASAN HASIL PENELITIAN}

Berdasarkan hasil penelitian dan analisisnya, maka pada bagian ini akan dibahas sesuai dengan permasalahan yang diteliti. Adapun permasalahan yang peneliti fokuskan pada dua indikator yakni 1. (Model Pembelajaran Kooperatif Tipe STAD), 2. (Minat Belajar).

\section{Model Pembelajaran Kooperatif Tipe STAD}

Menurut Hamdayama (2016), Pembelajaran kooperatif tipe STAD (Student Teams Achievement Division) atau kelompok siswa berprestasi, merupakan salah satu tipe pembelajaran kooperatif yang menekankan struktur-struktur khusus yang dirancang untuk mempengaruhi pola-pola interaksi siswa dan memiliki tujuan untuk meningkatkan penguasaan materi pelajaran.

Adapun langkah-langkah yang digunakan dalam model pembelajaran kooperatif tipe STAD yaitu:

Langkah 1. Persiapan
Pada tahap ini yang akan dilakukan dalam proses belajar mengajar yaitu kegiatan pendahuluan yang terdiri dari:

a. Memberi salam

b. Membuka kegiatan belajar mengajar dengan doa

c. Mengecek kehadiran, kebersihan dalam kelas, dan kerapihan

d. Mempersiapkan mata pelajaran yang akan diajarkan melalui RPP

e. Lembar kerja siswa yang sesuai dengan model pembelajaran kooperatif tipe STAD

Langkah 2. Pembentukan Kelompok

Dalam pembentukan kelompok yang akan disesuaikan dengan model pembelajaran kooperatif tipe STAD.

a. Guru membagi 6 kelompok yang beranggotakan 4-5 orang siswa yang merupakan campuran menurut prestasi, latar belakang sosial, ras, suku, dan jenis kelamin.

b. Dalam pembagian kelompok siswa diharapkan untuk dapat berinteraksi dengan baik dengan sesama anggota kelompok.

Langkah 3. Guru Menyajikan Pelajaran

Dalam langkah ini guru menyajikan pelajaran untuk menambah pengetahuan siswa dalam model pembelajaran kooperatif tipe STAD.

a. Guru menjelaskan materi demokrasi yang akan didiskusikan oleh masing-masing kelompok.

b. Guru akan menggunakan nilai tes awal (pre-test) sebagai dasar pembentukan masing-masing kelompok.

Langkah 4. Guru memberi tugas kepada kelompok untuk dikerjakan oleh anggotaanggota kelompok. Anggotanya yang sudah mengerti dapat menjelaskan pada anggota lainnya sampai semua anggota dalam kelompok itu mengerti.

a. Setiap kelompok mendiskusikan apa yang sudah dijelaskan oleh guru.

b. Guru memberi bimbingan disetiap kelompok dalam mengerjakan tugas di kelompok masing-masing. 
c. Setelah selesai mengerjakan dan mendiskusikan materi yang telah dijelaskan, setiap kelompok mempresentasikan hasil diskusinya

Langkah 5. Guru memberikan kuis atau pertanyaan kepada seluruh siswa . pada saat menjawab kuis tidak boleh saling membantu

a. Guru memberikan kuis kepada seluruh siswa mengenai materi yang telah di pelajari

b. Siswa yang dapat menjawab diberikan penghargaan sedangkan yang tidak menjawab dapat diberikan nasihat agar supaya pada pertemuan berikut dapat berpartisipasi dengan baik.

Langkah 6. Memberikan evaluasi

a. Guru memberikan evaluasi pada akhir pelajaran untuk mengetahui seberapa banyak siswa yang berhasil dalam proses pembelajaran

b. Pada akhir pembelajaran evaluasi sangat penting dalam mengukur pengetahuan siswa dan apakah guru berhasil atau tidak.

Langkah 7. Memberikan kesimpulan

Pada tahap terakhir guru bersama siswa megulang materi yang telah dipelajari dalam proses belajar mengajar. Dan di Minta kepada beberapa siswa untuk mengulang materi tersebut agar supaya mereka belajar.

\section{Minat Belajar}

Untuk memudahkan pemahaman tentang minat belajar maka dalam pembahasan ini terlebih dahulu akan diuraikan minat dan belajar. Menurut syaiful Djamarah, (2008;132), minat adalah kecenderungan yang menetap untuk memperhatikan dan mengenang beberapa aktivitas. Seseorang yang berminat terhadap aktivitas akan memperhatikan aktivitas itu secara konsisten dengan rasa senang. Minat merupakan sifat yang relatif menetap pada diri seseorang. Minat besar pengaruhnya terhadap kegiatan seseorang sebab dengan minat siswa akan melakukan sesuatu yang diminatinya. Sebaliknya tanpa minat seseorang tidak mungkin melakukan sesuatu. Adapun indikator dari minat belajar yaitu:

a. Perasaan Senang Terhadap Proses Belajar Apabila seorang siswa memiliki perasaan senang terhadap pelajaran tertentu maka tidak akan ada rasa terpaksa untuk belajar. Dengan adanya perasaan senang dari siswa dalam mengikuti proses belajar mengajar maka siswa akan senang dalam membuat tugas dan saat guru menerangkan materi yang dipelajari maka perhatian siswa fokus tertuju pada pelajaran yang diajarkan dan mampu mengerjakan tugas yang diberikan. Untuk itu dalam proses belajar mengajar dibutuhkan rasa senang untuk mengikuti pelajaran yang sedang berlangsung agar supaya siswa tidak akan bosan dalam mengikuti proses belajar. Contohnya yaitu siswa yang merasa senang dalam proses belajar akan dapat mengerjakan tugas dengan baik dan hadir tepat waktu saat jam pelajaran dimulai. Dengan adanya perasaan senang dari siswa dalam mengikuti proses belajar maka siswa akan memiliki minat yang tinggi dan mampu mengerjakan tugas dengan baik sehingga siswa dapat memiliki hasil yang baik.

b. Keterlibatan Siswa

Ketertarikan seseorang akan obyek yang mengakibatkan orang tersebut senang dan tertarik untuk melakukan atau mengerjakan kegiatan dari obyek tersebut. Dalam proses belajar ketertarikan seseorang sangat diperlukan karena apabila mereka tertarik dengan pelajaran yang sedang di jelaskan maka siswa akan merasa senang untuk terlibat dalam proses belajar. Tetapi sebaliknya apabila seseorang tidak tertarik dengan pelajaran yang sedang dijelaskan maka ia tidak ingin terlibat dalam proses belajar yang sedang berlangsung. Contohnya aktif dalam diskusi, aktif bertanya, dan aktif menjawab pertanyaan dari guru. Dalam proses belajar sangat dibutuhkan keterlibatan siswa karena apabila siswa berhasil maka guru juga akan dikatakan berhasil. Untuk itu sangat di butuhkan keterlibatan siswa untuk berperan aktif dalam proses belajar seperti apabila 
dalam kelompok harus berperan aktif dalam melakukan diskusi bersama dengan teman siswa yang lain, aktif bertanya apabila adanya kelompok lain yang melakukan presentasi serta mampu menjawab pertanyaan yang diberikan kelompok lain. Dengan adanya keterlibatan siswa maka akan berdampak positif pada siswa tersebut dan akan meningkatkan minat belajar yang tinggi dari siswa tersebut.

c. Ketertarikan siswa dalam proses belajar

Dengan adanya ketertarikan dari siswa pada sesuatu benda, orang, kegiatan atau bisa berupa pengalaman afektif yang dirangsang oleh kegiatan itu sendiri. Untuk itu ketertarikan siswa merupakan daya dorong yang sangat penting agar meningkatkan minat belajar siswa itu sendiri. Apabila tidak ada daya dorong untuk meningkatkan ketertarikan siswa dalam mengikuti pelajaran maka siswa tidak memiliki semangat untuk belajar dan tidak ingin berpartisipasi. Contohnya dengan adanya ketertarikan dalam mengikuti pelajaran maka siswa akan antusias dalam mengikuti pelajaran dan tidak menunda tugas dari guru. Ketertarikan siswa sangat dibutuhkan untuk meningkatkan minat belajar dari dalam diri siswa. Ketertarikan siswa dalam proses belajar sangat perlu karena apabila siswa tertarik dengan pelajaran yang sedang dipelajarinya maka dengan sendirinya minat siswa tersebut akan muncul dan siswa tersebut akan senang mengikuti pelajaran dan apabila ada tugas maka siswa tersebut akan mengerjakannya dan tidak akan menunda tugas yang diberikan.

d. Adanya perhatian siswa dalam proses belajar

Minat dan perhatian merupakan dua hal yang dianggap sama dalam penggunaan sehari-hari, perhatian siswa merupakan konsentrasi siswa terhadap pengamatan dan pengertian, dengan mengesampingkan yang lain. Siswa memiliki minat pada obyek tertentu maka dengan sendirinya akan memperhatikan obyek tersebut. Dengan adanya perhatian dari siswa maka siswa dapat membuat tugas yang diberikan oleh guru dan juga bisa mengerti tentang materi yang dijelaskan. Contohnya mendengarkan penjelasan guru dan mencatat materi. Perhatian siswa sangat diperlukan dalam proses belajar karena apabila siswa memperhatikan pelajaran yang sedang dijelaskan oleh guru, maka siswa akan dapat mengerti dengan baik pelajaran yang telah dijelaskan.

\section{KESIMPULAN DAN SARAN Kesimpulan}

Berdasarkan uraian pada bab sebelumnya, maka peneliti dapat menyimpulkan beberapa hal sebagai berikut: 1. Model pembelajaran kooperatif tipe STAD yang sudah diterapkan dapat meningkatkan minat belajar siswa dan dapat menciptakan pembelajaran yang menarik sehingga siswa tertarik untuk belajar dan ikut berpartisipasi dalam proses belajar.

2. Pada model pembelajaran kooperatif tipe STAD diskusi dan kerja kelompok memberikan kesempatan kepada siswa untuk dapat berpikir, berdiskusi bersama teman-teman sekelompoknya dan membuat kuis yang membuat siswa tertarik untuk belajar.

3. Penerapan model pembelajaran tipe STAD yang sudah diterapkan ternyata dapat meningkatkan minat belajar pada mata pelajaran PKn pada siswa SMP Negeri 4 Beo khususnya untuk kelas VIII A.

\section{Saran}

\section{Bagi Guru}

Bagi guru PKn penguasaan model pembelajaran kooperatif tipe STAD memungkinkan berkembangnya prestasi siswa, dan guru harus mampu memberi motivasi sekaligus fasilitator siswanya agar dapat mencapai proses pembelajaran yang lebih efektif dan efisien. Dan juga dalam penerapan model pembelajaran diperlukan kemampuan tentang jenis-jenis model pembelajaran yang sangat inovatif untuk 
meningkatkan mutu pembelajaran yang lebih baik.

\section{Bagi Siswa}

Keberhasilan prestasi belajar tidak tergantug pada orang lain tetapi lebih banyak ditentukan oleh diri sendiri. Untuk itu siswa harus terlibat dalam proses belajar secara fisik maupun mental untuk mempermudah tercapainya tujuan pembelajaran.

\section{Bagi sekolah}

Dalam upaya mengembangkan pembelajaran yang efektif, inovatif dan juga efisien maka model pembelajaran kooperatif tipe STAD perlu diterapkan terutama dalam proses pembelajaran PKn pada siswa Kelas VIII A di SMP Negeri 4 Beo di Lobbo.

\section{DAFTAR PUSTAKA}

Arends, Richard I. 2007. Learning to Teach. Yogyakarta: Pustaka Belajar.

Arikunto, S. $\quad$ 2002. Prosedur Suatu Penelitian: Pendekatan Praktek. Jakarta:Rineka Cipta. Chaplin, J.P. 2008. Kamus Lengkap Psikologi. Jakarta: PT Raja Grafindo Persada.

Daryanto. 2008. Evaluasi Pendidikan. Jakarta: PT Rineka Cipta.

Dimyati dan Mudjiono. 2002. Belajar dan Pembelajaran. Jakarta: Rineka Cipta dan Depdikbud .

Djamarah, S. B. 2008. Psikologi Belajar. Jakarta: Rineka Cipta.

Ertikanto. 2016. Teori Belajar dan Pembelajaran. Lampung: Media Akademi.

Gunawan. 2016. Metode Penelitian Kualitatif: Teori dan Praktik. Jakarta: PT Bumi Aksara. Hamdayana, J. 2016. Metodologi Pengajaran. Jakarta: PT Bumi Aksara.

Hamdani. 2011. Strategi Belajar Mengajar. Bandung: Pustaka Setia.

Hamidi. 2004. Metode Penelitian Kualitatif: Aplikasi Praktis Pembuatan Proposal dan Laporan Penelitian. Malang: UMM Press.

Ihsana. 2016. Belajar dan Pembelajaran:Konsep Dasar Metode dan Aplikasi Nilai-nilai Spiritualitas dalam Proses Pembelajaran. Yogyakarta: Pustaka Belajar.

Isjoni 2009. Cooperative Learning . Bandung:Alfabeta.

Maleong. 2000. Metodologi Penelitian Kualitatif. Bandung: PT Rosdakarya.

Pangalila, T. 2017. Peningkatan Civic Disposition Siswa Melalui Pembelajaran Pendidikan Kewarganegaraan (PKn). Dalam: Jurnal Pendidikan Kewarganegaraan Unlam. 2017. Vol. 7. No. 1.

Ridwan. 2010. Metode \& Teknik Menyusun Proposal Penelitian. Jakarta: Alfabeta.

Rusman, dkk. 2010. Model-model Pembelajaran: Mengembangkan Profesionalisme Guru. Jakarta: PT. Raja Grafindo Persada.

Rusman. 2012. Model-model Pembelajaran: Mengembangkan Profesionalisme Guru. Jakarta: PT. Raja Grafindo Persada.

Shoimin. 2014. Model Pembelajaran Inovatif dalam Kurikulum 2013. Yogyakarta:AR-ruz Media.

Slameto. 2003. Belajar dan Faktor-faktor yang mempengaruhinya. Jakarta:Rineka Cipta.

Slavin, E. R. 2008. Cooperative Learning Teori Riset dan Praktik. Bandung: NusaMedia.

Sugiyono, 2010. Metode Penelitian Kuantitatif, Kualitatif dan R\&D. Bandung: Alfabeta.

Suhana. 2014. Konsep Strategi Pembelajaran. Bandung: PT. Refika Aditama.

Sumantri, Numan. 2001. Menggagas Pembaharuan Pendidikan IPS. Bandung: Rosda Karya.

Suparno. 2007. Filsafat Konstruktivisme dalam Pendidikan. Yogyakarta: Kanisius

Suprijono. 2009. Cooperative Learning Teori dan Aplikasi PAIKEM. Yogyakarta: Pustaka Pelajar. 
Susanto. 2013. Teori Belajar dan Pembelajaran di Sekolah Dasar. Jakarta: Kencana Prenada Media Group.

Suyanti, R, Dwi. 2010. Strategi Pembelajaran Kimia. Yogyakarta: Graha Ilmu.

Syah, M. 2003. Psikologi Belajar. Jakarta: PT. Raja Grafindo Persada.

Trianto. 2009. Mendesain Model Pembelajaran Inovatif-Progresif. Jakarta:Kencana Prenada Group.

Winarto. 2014. Pembelajaran Pendidikan Kewarganegaraan: Isi, Strategi, dan Penilaian. Jakarta: PT. Bumi Aksara.

Zubaidi. 2007. Pendidikan Kewarganegaraan. Yogyakarta: Paradigma. Bandung:Refika Aditama.

\section{Referensi Undang-Undang}

Peraturan Menteri Pendidikan Nasional RI No.22 Tahun 2006

Undang-undang Guru dan Dosen No 14 Tahun 2005

Referensi Internet:

http://dokumen,tips/,http://elib.unikom.ac.id,http://el-kawaqi,blogspot.co.id,dan http://ringkasteori, blogspot.co.id(diakses Tanggal 24 Juli 2017)

http://spasikita.blogspot.co.id/2015/01/variasi-mengajar.html(di akses Tanggal 5 Agustus $\underline{2017)}$

https://kirimtugas.wordpress.com/2014/06/27/variasi-mengajar-2/ (diakses Tanggal 5 Agustus 2017)

http://www.sarjanaku.com/2012/12/pengertian-minat-belajar-siswa-menurut.html (di akses Tanggal 16 Agustus 2017) 